\title{
BIOMASS ENERGETIC POTENTIAL FROM TIMBER HARVESTING AT DIFFERENT TIMES OF STORAGE
}

\author{
Diego Oro ${ }^{1}$, Eduardo da Silva Lopes²*; Dimas Agostinho da Silva ${ }^{3}$; Everton Hillig²; Stefan Karl Pelz ${ }^{4}$ \\ ${ }^{1}$ Universidade Estadual do Centro-Oeste, Programa de Pós-Graduação em Ciências Florestais, Irati, Paraná, Brasil - \\ diegoorosh@hotmail.com \\ ${ }^{2 *}$ Universidade Estadual do Centro-Oeste, Departamento de Engenharia Florestal, Irati, Paraná, Brasil - eslopes@unicentro.br / \\ hillig@hotmail.com \\ ${ }^{3}$ Universidade Federal do Paraná, Departamento de Engenharia e Tecnologia Florestal, Curitiba, Paraná, Brasil - dimas@ufpr.br \\ ${ }^{4}$ Universidade de Ciências Florestais Aplicadas de Rottenburg, Rottenburg am Neckar, Baden-Würtemberg, Alemanha-pelz@consence.org
}

\begin{abstract}
This research aimed to characterize the energetic potential of chips of biomass residues from timber harvesting, stored outdoors in the field and indoors in the industry throughout different storage times, in order to improve the potential of the materials for energy generation. The study was performed in operational areas of a forestry company located in the Northeast region of the state of Santa Catarina, Brazil, in a Pinus taeda stand. Chips stored in the different storage types were evaluated at the times of $30,60,90,120,150$, and 180 days, according to the following physical and chemical parameters: moisture content, calorific value, and ash content. Data were subjected to analysis of variance and to the Tukey's post hoc means comparison test at $95 \%$ of probability. The results showed that the lowest moisture content was obtained in chips stored indoors for 60 days, whereas for chips stored outdoors the lowest moisture content occurred at 30 days. The chips stored outdoors for 30 days showed a higher calorific value of $4,792 \mathrm{Kcal} . \mathrm{Kg}^{-1}$, whereas chips stored indoors for 60 days had calorific value equivalent to the other storage times, $4,706 \mathrm{Kcal} . \mathrm{Kg}^{-1}$. Regarding the ash content, the best storage time for chips stored outdoors was 30 days, presenting an average ash content of $0.9 \%$. Meanwhile, in the indoors storage, the ash content of the chips remained at low levels throughout the evaluated period. The indoor chip storage has proven to be the best option for use of biomass residues from timber harvesting for energy purposes. Keywords: Timber harvesting, calorific value, energetic production
\end{abstract}

\section{Resumo}

Potencial energético de biomassa de colheita de madeira em diferentes períodos de estocagem. Esta pesquisa objetivou realizar uma caracterização energética de cavacos obtidos de biomassa residual da colheita de madeira estocada no campo e sob abrigo na indústria em diferentes períodos de tempo, visando subsidiar o melhor aproveitamento dos materiais para produção de energia. Foi realizada nas áreas operacionais de uma empresa florestal da região nordeste de Santa Catarina, Brasil, em povoamentos de Pinus taeda. Foram avaliados cavacos da biomassa residual da colheita de madeira estocada no campo e de estocados sob abrigo na indústria em diferentes períodos: 30, 60, 90,120, 150 e 180 dias, pelos parâmetros físico-químicos: teor de umidade, poder calorífico e teor de cinzas. Os dados passaram pela análise de variância e as médias comparadas pelo teste de Tukey a $95 \%$ de probabilidade. Os resultados mostraram que os menores teores de umidade foram obtidos nos cavacos estocados na indústria em 60 dias, enquanto os da biomassa residual estocada no campo, aos 30 dias. Os cavacos estocados no campo por 30 dias apresentaram poder calorífico superior a 4.792 $\mathrm{Kcal} . \mathrm{Kg}^{-1}$, enquanto os estocados na indústria ao abrigo por 60 dias tiveram poder equivalente aos demais períodos, $4706 \mathrm{Kcal} . \mathrm{Kg}^{-1}$. Sobre o teor de cinzas, o melhor período de estocagem da biomassa residual no campo ocorreu aos 30 dias (média de 0,9\%), enquanto, na indústria, o teor de cinzas manteve-se com baixos valores ao longo do período avaliado. A estocagem sob abrigo na indústria mostrou ser a melhor opção para aproveitamento da biomassa residual da colheita de madeira para fins energéticos.

Palavras-chave: Colheita de madeira, poder calorífico, produção energética.

\section{INTRODUCTION}

Biomass concerns any organic material obtained from plant species, which capture and store solar energy through photosynthesis that can be converted into useful forms of energy, such as heat, electricity and liquid fuels (AKPINAR et al., 2008). Among renewable energy sources, forest biomass stands out. It is originated from wood residues of forest harvesting, waste of industrial processing and energy forestry, which can be employed in steam and electricity cogeneration, in thermoelectric plants, in the pulp and paper industry, in grain drying, among others (SOUZA et al., 2012). 
Brand (2010) points out some beneficial aspects concerning the use of biomass for energy production, highlighting its low ash and sulfur content; renewable characteristics; contribution in neutralizing the emission of greenhouse gases by their fixation; high productivity in tropical and subtropical regions; possibility of use in solid, liquid or gaseous form; and its capacity of thermal, electrical and mechanical energy generation.

However, for the best use of biomass as energy source, it is important to know their physical and chemical characteristics, which can be influenced by the type and time of storage (SOUZA et al., 2012; VALE et al., 2011; LEITE et al., 2014). Leite et al. (2014) and Vale et al. (2011) also claim that the energy efficiency of combustion systems depends on the material characteristics regarding its calorific value, volatile matter and ash content. Souza et al. (2012) report that the moisture content and calorific value are important parameters that should be considered when biomass is used for energy generation.

Brand et al. (2012) point out that the storage of biomass should be performed regardless market factors, aiming to control its physical and chemical properties to improve its performance in the energy generation process. In this regard, Brand and Muñiz (2010) mention the need for storage of forest biomass, which can reduce the moisture content to around $30 \%$, in order to obtain greater efficiency in energy generation.

Neuhof et al. (2014) state that wood chips should be stored for an appropriate time aiming its rapid drying, which can increase the useful life of the material and avoid the loss of energy potential, since considerable losses can occur when the material is not properly stored. In this respect, Brand et al. (2011) analyzed the energy changes of pine biomass, concluding that the time of storage affected the energy potential of the materials, as well as metabolites or components of wood chips.

Another important feature concerns to the type of storage of biomass residues and wood chips, which may also affect the chemical and physical properties of materials. Furthermore, residue piles should not be placed too close to each other to favor the drying process. In turn, Neuhof et al. (2014) highlight the need of storing wood chips in order to favor the rapid drying, increase the useful life of the material, avoid reducing the energy potential, and ensure the quality of the chips. However, regarding outdoor storage, the authors state that the best way is to not carry out the processing of the material and leave it "in natura", avoiding a likely loss of 2 to $4 \%$ of energy potential. Scholz (2005) affirms that the storage of the material sheltered from the rain could lead to a reduction of $10 \%$ of moisture content.

Therefore, this study aimed to perform an energetic characterization of woods chips of biomass residues from timber harvesting stored in different types and periods of time, aiming the best use of the material for energy generation.

\section{MATERIAL AND METHODS}

This study was performed in a forestry company located in the Northern region of the state of Santa Catarina, Brazil, at the geographical coordinates of $26^{\circ} 17^{\prime} 55^{\prime} \mathrm{S}$ and $51^{\circ} 00^{\prime} 04^{\prime}$ ' W. According to the Köppen climatic classification, the region has $\mathrm{Cfb}$ climate type, characterized as humid subtropical mesothermal climate, with no defined dry season. Average annual temperature is $17.9{ }^{\circ} \mathrm{C}$, annual precipitation is $1,523.9 \mathrm{~mm}$ and average altitude is $780 \mathrm{~m}$. Meteorological data recorded throughout the study period are presented in Table 1.

Table 1. Climatic conditions recorded throughout the study period.

Tabela 1. Condições climáticas obtidas durante a realização do estudo.

\begin{tabular}{ccccc}
\hline $\begin{array}{c}\text { Collection Period } \\
(\mathbf{m o n t h} / \mathbf{y e a r})\end{array}$ & $\begin{array}{c}\text { Average } \\
\text { Precipitation } \\
(\mathbf{m m})\end{array}$ & $\begin{array}{c}\text { Average } \\
\text { Temperature } \\
(\mathbf{})\end{array}$ & $\begin{array}{c}\text { Average Relative } \\
\text { Humidity } \\
(\boldsymbol{\%})\end{array}$ \\
\hline $\mathbf{1}$ & September/2014 & 96.4 & 20.8 & 78.5 \\
$\mathbf{2}$ & October/2014 & 96.4 & 20.8 & 78.5 \\
$\mathbf{3}$ & November/2014 & 157.8 & 21.4 & 78.9 \\
$\mathbf{4}$ & December/2014 & 292.6 & 22.3 & 81.5 \\
$\mathbf{5}$ & January/2015 & 121.8 & 23.3 & 82.6 \\
$\mathbf{6}$ & February/2015 & 184.4 & 22.2 & 85.7 \\
$\mathbf{7}$ & March/2015 & 189.4 & 21.3 & 83.0 \\
\hline
\end{tabular}

The study was performed by using biomass residues from timber harvesting in Pinus taeda stands at the age of 14 years, spacing of $2.5 \times 2.5 \mathrm{~m}$ and average total volume of $650 \mathrm{~m}^{3} \cdot \mathrm{ha}^{-1}$. The experimental design was the bi-factorial type, from which two factors were assessed: the type, and the time of biomass storage from wood residues.

Regarding the type of storage, two treatments were evaluated: residues from timber harvesting stored outdoors, and residues chips processed after harvesting wood and subsequently stored in the industry under cover. 
For this purpose, twelve piles of residues were gathered at seven days after the operation of wood harvesting was complete; each one represented the time of storage and type of treatment.

The residues piles comprised logs of diameter below $8 \mathrm{~cm}$ and materials (branches and needles) with individual pile volume of $13 \mathrm{~m}^{3}$, which resulted in the first type of biomass residues storage (Figure 1a). The second type of storage was comprised of chips from biomass residues processed seven days after the harvest. They were transported and stored in industrial shed in piles of $8 \mathrm{~m}^{3}$, within cover for the weather and natural ventilation (Figure 1b). Both types of materials storage were evaluated at 30, 60, 90, 120, 150, and 180 days, from October 2014 to March 2015.

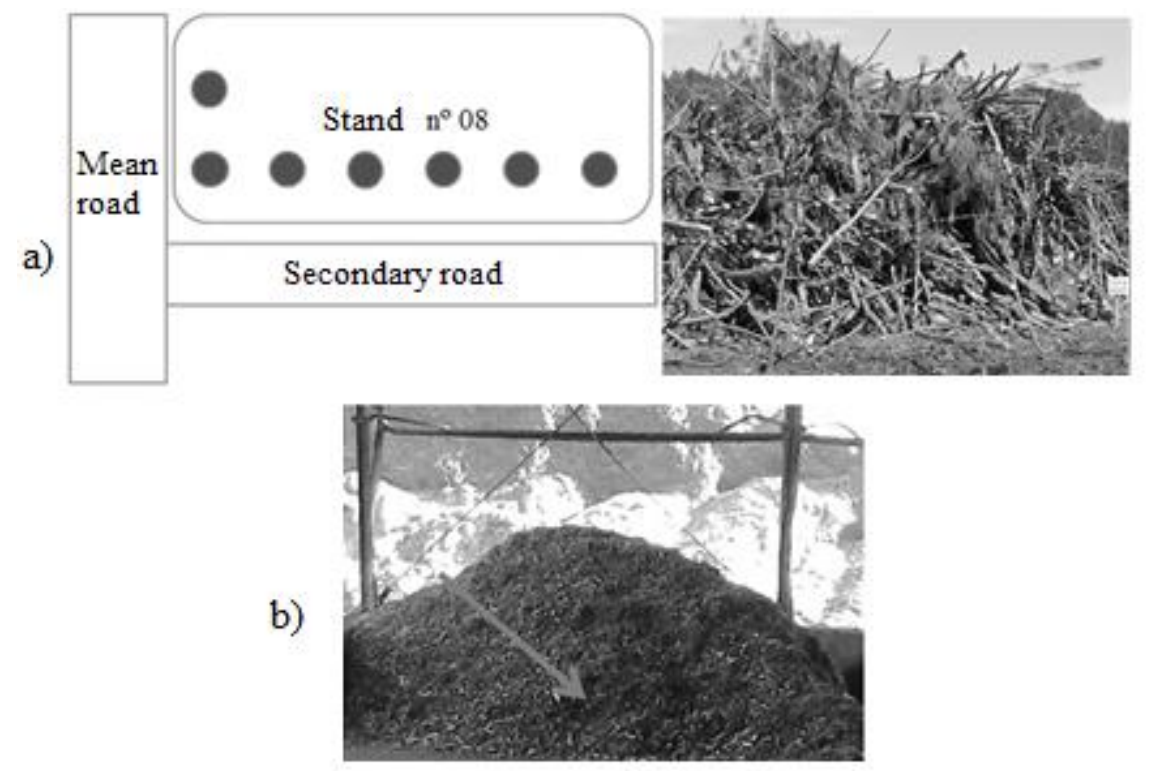

Figure 1. Biomass residues from timber harvesting stored in the field (a), and chips processed and stored in industrial shed (b).

Figura 1. Biomassa residual da colheita de madeira estocada no campo (a) e cavacos processados e estocados em galpão industrial (b).

On the first type of storage, piles of biomass residues were processed in each one of the different periods of storage time (30, 60, 90, 120, 150, 180 days) by using a mobile wood chipper (Veermer Brand, HG 6000 TX model, with nominal motor power of $630 \mathrm{hp}$ and equipped with hammers system). Five chip samples (repetitions) of $1 \mathrm{~kg}$ were collected, and then packed in polyethylene bags to maintain humidity and sent to laboratory analysis. Regarding the second type of storage, in each storage time, five samples of $1 \mathrm{~kg}$ were collected from different parts of the pile stored in the industry, and the material was homogenized and packed in polyethylene bags for laboratory analysis.

The physical and chemical analyses of chips produced in different types and times of storage were performed by assessing the following variables: moisture content, calorific value, and ash content. To determine the moisture content of chips, samples were initially weighed in analytical balance of $0.1 \mathrm{mg}$ to measure the wet weight. Then, samples were taken to dry in oven at $105^{\circ} \mathrm{C}$ up to constant weight and taken to the desiccator to obtain the dry weight, in compliance with the standards requirements of NBR 14929 from Brazilian Association of Technical Standards (ABNT, 2003) and Standard Test Method for Moisture Analysis of Particulate Wood Fuels - ASTM E871-82 (ASTM, 2013). Moisture content was obtained by the expression:

$$
M C(\%)=\frac{W-D}{W} \cdot 100
$$

In which: $\mathrm{MC}(\%)=$ wet basis moisture content; $\mathrm{W}=$ wet weight of sample $(\mathrm{g}) ; \mathrm{D}=$ dry weight of sample $(\mathrm{g})$.

Gross calorific value was obtained from a calorimeter (IKA-WERNE C5000 brand) in compliance with the standards ASTM E 711-87 (ASTM, 2004) and the German Institute for Standardization (DIN 15104). Samples were dried and grinded to obtain a two-gram sub-sample, which was inserted into the calorimeter to obtain the gross calorific value.

FLORESTA, Curitiba, PR, v. 48, n. 1, p. 09-18, jan./mar. 2018

Oro. D. et.al.

ISSN eletrônico 1982-4688

DOI: $10.5380 /$ rf.v48 i 1.46628 
The net calorific value, which represents the calorific value produced by the wood in actual humidity conditions, was obtained from the lower calorific value. This value corresponds to the energy generated less the amount of water formed during the combustion of the hydrogen of constitution from wood. The net calorific value was then obtained by the following expression:

$$
N C V=\frac{L H V-(6 . W)}{100+W} .100
$$

In which: $\mathrm{NCV}=$ net calorific value; $\mathrm{LHV}=$ lower calorific value; $\mathrm{W}=$ moisture content of the wood on dry basis.

The lower calorific value was calculated according to the following expression:

$$
L C V=G C V-\left(600.9 \cdot \frac{\% H}{100}\right)
$$

In which: $\mathrm{LHV}=$ lower calorific value; $\mathrm{GCV}=$ gross calorific value; $\% \mathrm{H}=$ hydrogen content.

The ash content was obtained from the combustion of organic compounds and oxidation of inorganic compounds in a muffle furnace under strict control of mass, temperature and time. Chip samples, without the volatiles, were put in crucibles and taken to the inside of the muffle at $700{ }^{\circ} \mathrm{C}$ for six hours. At the end of the procedure, ash content was obtained by the following expression:

$$
A=\frac{M_{4}-M_{3}}{M_{1}-M_{3}} .100
$$

In which: $\mathrm{A}=$ ash content $(\%) ; \mathrm{M}_{1}=$ dry weight of sample + crucibles; $\mathrm{M}_{3}=$ weight of crucibles without material; $\mathrm{M}_{4}=$ ash weight + crucibles after 6 hours in muffle $(\mathrm{g})$.

The values of physical and chemical parameters of the chips were statistically analyzed by using analysis of variance (ANOVA) and, when necessary, the averages from the treatments within each factor were compared by Tukey's test at $95 \%$ probability.

\section{RESULTS AND DISCUSSION}

\section{Moisture content}

The wet basis moisture contents of chips from biomass residues stored outdoors and chips processed and stored indoors are shown in Table 2 . According to the values, treatments involving chips stored indoors showed a reduction in moisture content, with values below $40 \%$ at 60 days $(35.8 \%)$. This indicates a significant reduction in moisture content during the study period when compared to the initial moisture $53 \%$.

After 120 days of storage, chips presented lower moisture content, but there was no statistically significant difference compared to the storage periods of $60,90,150$, and 180 days. This result indicated a stabilization in the moisture content at 60 days of storage. Therefore, this period can be regarded as the appropriate time of storage in order to use the chips as energy source, concerning the moisture content in the indoor storage.

Regarding the outdoor storage, stabilization in moisture content started at 30 days, although the storage time of 60 days resulted in statistically similar value $(50.1 \%$ and $47.1 \%$, respectively). Thus, storage time between 30 and 60 days was the most suitable concerning moisture content for outdoor storage. After 90 days of storage, it was observed a $10 \%$ rise in moisture content (Figure 2). This time of storage did not differ statistically from longer times. Such increase in moisture content after 60 days of storage can be regarded to the rain of the period. The effect of rain on moisture content of chips cannot be noticed in the indoor storage, evidently. 
Table 2. Average moisture content of chips from biomass residues stored outdoors and indoors.

Tabela 2. Teor de umidade médio de cavacos de biomassa residual estocada no campo e cavacos estocados na indústria.

\begin{tabular}{|c|c|c|}
\hline \multirow{3}{*}{$\begin{array}{c}\text { Factor Time of Storage } \\
\text { (days) }\end{array}$} & \multicolumn{2}{|c|}{ Factor type of storage } \\
\hline & Outdoorstorage & Indoor storage \\
\hline & \multicolumn{2}{|c|}{ Moisture content (\%) } \\
\hline 30 & $50.1 \mathrm{aB}$ & $45.0 \mathrm{bA}$ \\
\hline 60 & $47.1 \mathrm{aB}$ & $35.8 \mathrm{bB}$ \\
\hline 90 & $57.5 \mathrm{aA}$ & $32.6 \mathrm{bB}$ \\
\hline 120 & $58.3 \mathrm{aA}$ & $30.0 \mathrm{bB}$ \\
\hline 150 & $60.7 \mathrm{aA}$ & $31.1 \mathrm{bB}$ \\
\hline 180 & $60.4 \mathrm{aA}$ & $31.0 \mathrm{bB}$ \\
\hline
\end{tabular}

In which: Averages followed by the same letter are not significantly different; lower case letters indicate comparison in the rows (type of storage); upper case letters indicate comparison in columns (time of storage).

The initial reduction in moisture content of biomass residues observed in this study showed different variation patterns when compared to that found by Brand et al. (2012) for Pinus taeda logs with bark. The authors found that most moisture loss was achieved in the period between 60 and 120 days of storage. This difference of variation occurs due to the fact that logs are larger in size than chips and, therefore, require more time for moisture loss.

Vale et al. (2011) state that the moisture content of stored residues varies according to the particles geometry, the time of storage, and site conditions (relative humidity and temperature), among other factors. Whereas, Brand et al. (2014) state that changing the size of the particles of biomass residues accelerates the rate of water loss during the storage process.

It is important to note that moisture content is a factor of great importance in the use of biomass residues as energy source, since it has an inverse relationship with net calorific value. Additionally, high moisture content may hamper the storage process due to the proliferation of fungi and degradation of the material, as well as result in high transportation costs (VALE et al., 2011).

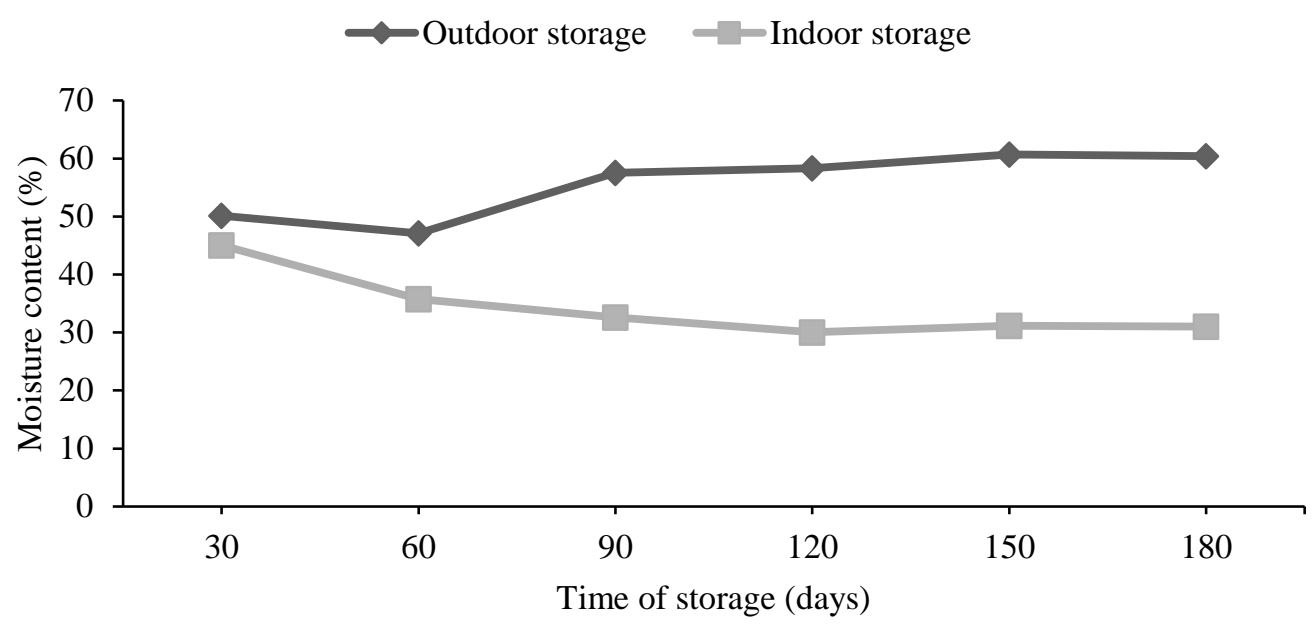

Figure 2. Variation in moisture content of chips from biomass residues in outdoor and indoor storage according to the time of storage.

Figura 2. Variação do teor de umidade dos cavacos de biomassa residual estocada no campo e dos cavacos estocados na indústria em função do tempo de estocagem.

By comparing the types of storage, it is clear that processing biomass residues and storing them indoor will allow the achievement and maintenance of lower moisture content of the material at 60 days, thus improving its characteristic for energy generation.

FLORESTA, Curitiba, PR, v. 48, n. 1, p. 09-18, jan./mar. 2018

Oro. D. et.al.

ISSN eletrônico 1982-4688

DOI: $10.5380 /$ rf.v48 i1.46628 


\section{Calorific value}

In Table 3, the results for calorific value of the chips stored indoors and outdoors throughout different storage times are presented. We can notice a significant differentiation in the net calorific value, which takes the momentary moisture content and hydrogen in the composition of the material into account.

Table 3. Gross calorific value $(\mathrm{GCV})$ and average net calorific value (NCV) of chips from forest biomass residues in outdoor and indoor storage.

Tabela 3. Poder calorífico superior (PCS) e poder calorifico líquido (PCLu) médio dos cavacos de biomassa residual estocada no campo e dos cavacos estocados na indústria.

\begin{tabular}{|c|c|c|c|c|}
\hline \multirow{2}{*}{$\begin{array}{c}\text { Factor time of } \\
\text { storage } \\
\text { (days) }\end{array}$} & \multicolumn{2}{|c|}{ GCV(kcal.kg-1) } & \multicolumn{2}{|c|}{ NCV(kcal.kg $\left.{ }^{-1}\right)$} \\
\hline & Outdoor storage & Indoor storage & Outdoor storage & Indoor storage \\
\hline 30 & $4,792 \mathrm{aA}$ & $4,758 \mathrm{aA}$ & $2,233 \mathrm{bA}$ & $2,447 \mathrm{aC}$ \\
\hline 60 & 4,372 bCD & $4,706 \mathrm{aA}$ & $2,143 \mathrm{bA}$ & $2,809 \mathrm{aB}$ \\
\hline 90 & $4,665 \mathrm{aAB}$ & $4,717 \mathrm{aA}$ & $1,833 \mathrm{bB}$ & $2,962 \mathrm{aAB}$ \\
\hline 120 & $4,505 \mathrm{bBC}$ & $4,736 \mathrm{aA}$ & $1,746 \mathrm{bBC}$ & $3,099 \mathrm{aA}$ \\
\hline 150 & $4,268 \mathrm{bDE}$ & $4,813 \mathrm{aA}$ & $1,544 \mathrm{bC}$ & $3,070 \mathrm{aAB}$ \\
\hline 180 & $4,130 \mathrm{bE}$ & $4,781 \mathrm{aA}$ & $1,509 \mathrm{bC}$ & $3,083 \mathrm{aAB}$ \\
\hline
\end{tabular}

In which: GCV = Gross calorific value; $\mathrm{NCV}$ = net calorific value. Averages followed by the same letter are not significantly different; lower case letters indicate comparison in the rows (type of storage); upper case letters indicate comparison in columns (time of storage).

Analyzing the gross calorific value, we can notice that biomass residues stored outdoors presented a significant loss of potential for energy generation throughout the storage period. The best time of storage was 30 days, which resulted in calorific value of $4,792 \mathrm{kcal}_{\mathrm{kg}}{ }^{-1}$, statistically different when compared to other storage times, except for the time of 90 days. The worst storage period was 180 days, which resulted in calorific value of $4,130 \mathrm{kcal} . \mathrm{kg}^{-1}$. It was not significantly different when compared to the time of 150 days.

Brand and Muñiz (2010), analyzing the gross calorific value, defined as occurrence of variation in energy generation when the calorific value of the material exceeded $3,000 \mathrm{kcal}_{\mathrm{kg}}{ }^{-1}$, obtained from 30 days of storage of the material.

Regarding the factor of storage time, we can notice that there was no significant variation in the gross calorific value for the material stored indoors. It remained constant after 30 days and this result was not observed in the material stored outdoors. However, the highest calorific value was observed at 150 days $\left(4,813 \mathrm{kcal}^{\mathrm{kg}} \mathrm{kg}^{-1}\right)$, followed by the 180 days of storage $\left(4,781 \mathrm{kcal} . \mathrm{kg}^{-1}\right)$. In this regard, Furtado et al. (2012) point out that the chemical composition of the material, the amount of lignin, cellulose and extractives, and the biomass composition, concerning the amount of wood and bark, may affect the calorific value significantly. Such variation is a common condition when it comes to wood residues from timber harvesting, which has varying types of materials, such as wood, thin and thick branches, and needles.

Biomass residues from timber harvesting stored outdoors "in natura" resulted in chips of inferior quality, concerning energy generation. This can be regarded to the decomposition process. The result showed that, when comparing both types of storage, the best type corresponds to processing chips and storing them indoors in the industry, ensuring better results and optimization of energy potential of the material.

Analyzing the net calorific value that results from gross calorific value, hydrogen of composition and moisture content of the biomass, we can clearly notice significant differences among storage types and times.

In the outdoor storage of biomass residues, the highest net calorific value was obtained at 30 days, $\left(2,233 \mathrm{kcal}_{\mathrm{kg}}{ }^{-1}\right)$. This value did not differ significantly from the one at 60 days, although it was different when compared to other storage times. The lowest net calorific value was $1,509 \mathrm{kcal}^{\mathrm{kg}} \mathrm{kg}^{-1}$ at 180 days. Such variation in calorific values agrees with the one found by Brand et al. (2012), who reported net calorific values of 1,341 to 2281 kcal. $\mathrm{kg}^{-1}$ for Pinus taeda residues with bark, considering a similar seasonal variation.

In the indoor storage, the highest net calorific value was observed at 120 days $\left(3,099 \mathrm{kcal}_{\mathrm{kg}} \mathrm{kg}^{-1}\right.$, which was not significantly different from the periods of 90, 150, and 180 days. The lowest net calorific value was observed at 30 days $\left(2,447 \mathrm{kcal} . \mathrm{kg}^{-1}\right)$. It differed from the other treatments, including a margin of $300 \mathrm{kcal}^{\mathrm{kg}} \mathrm{kg}^{-1}$. This indicates that chips require a minimum storage time of 60 days to achieve better quality for energy purposes.

When compared both types of storage, it can be observed that the indoor storage allowed the optimization of the energy potential of biomass residues by the gross calorific value as well as by the net calorific value. Also, 
in most cases, the net calorific value of biomass residues "in natura" stored outdoors presented the worst results. According to Figure 3, despite having statistical difference between types of storage, the net calorific value did not reach the margin of $300 \mathrm{kcal}_{\mathrm{kg}} \mathrm{kg}^{-1}$ at 30 days of storage, considering the same type of storage, which did not occur in other storage times investigated.

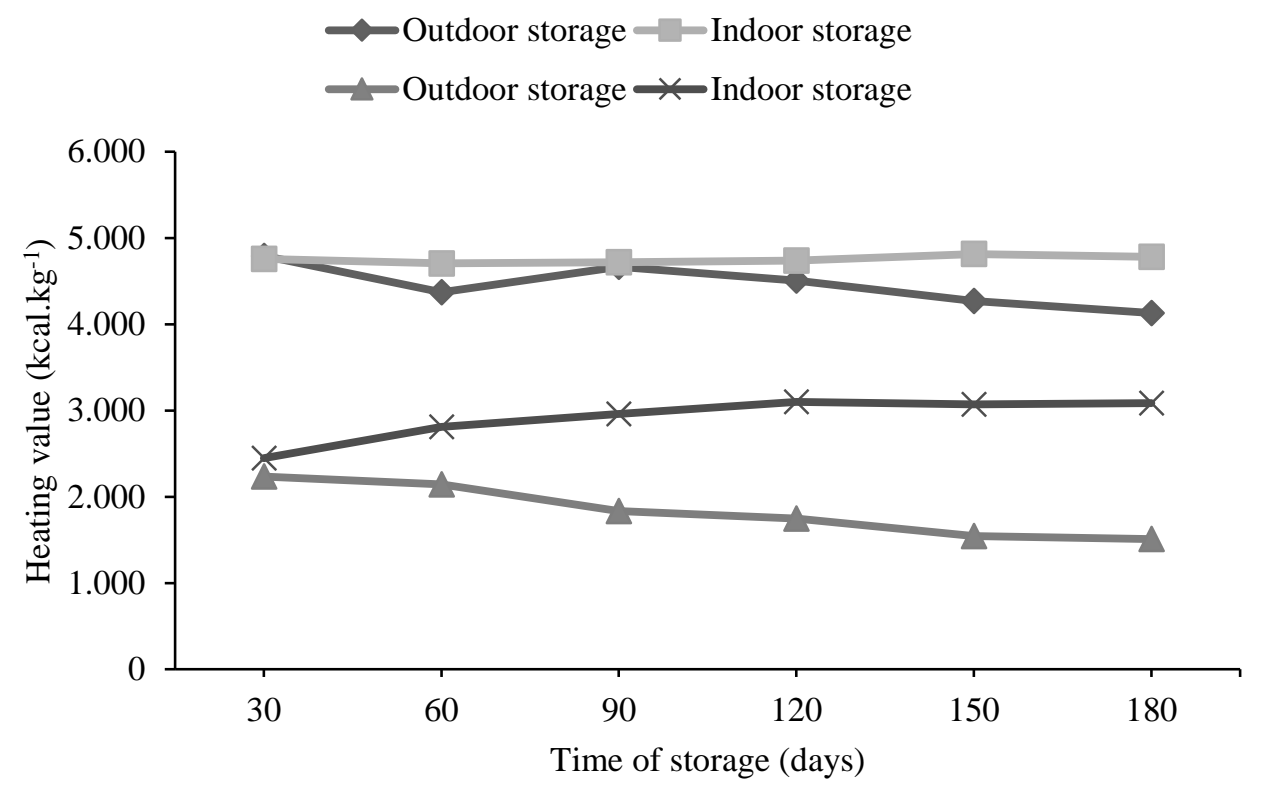

Figure 3. Variation of gross calorific value and net calorific value of biomass residues stored indoors and outdoors.

Figura 3. Comportamento do poder calorífico superior e poder calorífico líquido dos cavacos de biomassa residual estocada no campo e dos cavacos estocados na indústria.

Brand et al. (2014), studying the biomass of slabs and logs, reported that the ideal time of storage for energy generation is 120 days for these materials, since it allows higher calorific values. However, it is important to note that the results obtained in this study, in which biomass residues were processed and stored indoors as chips, reached good levels for energy generation as well.

Therefore, if the improvement of biomass residues for energy generation is desired, these materials should be processed as chips and stored indoors. It would result in an approximate increase of $30 \%$ in the net calorific value, which is directly affected by the decrease of moisture content after 30 days of storage.

\section{Ash content}

The ash content of wood chips processed from biomass residues from timber harvesting stored outdoors and indoors for different times is presented in Table 4. Considering the outdoor storage, the lowest average ash content was found at 30 days, with a value of $0.9 \%$, which was not significantly different from that at 90 days (3.2\%). The highest ash content was obtained at 180 days of storage $(12.1 \%)$.

The ash content obtained for biomass residues of Pinus taeda at age of 14 years and planted in a spacing of $2.5 \times 2.5 \mathrm{~m}$ is close to that reported by several authors in studies regarding biomass residues of Pinus taeda and Pinus patula (FURTADO et al., 2012; ALMEIDA et al., 2010, respectively). Analyzing chips stored indoors in the industry, we can notice stability in the ash content after 30 days. The lowest values occur between 60 and 150 days, although no significant difference was observed between storage times.

FLORESTA, Curitiba, PR, v. 48, n. 1, p. 09-18, jan./mar. 2018

Oro. D. et.al.

ISSN eletrônico 1982-4688

DOI: $10.5380 /$ rf.v48 i1.46628 
Table 4. Average ash content of chips from forest biomass residues stored outdoors and indoors.

Tabela 4. Teor médio de cinzas dos cavacos de biomassa residual estocada no campo e dos cavacos estocados na indústria.

\begin{tabular}{|c|c|c|}
\hline \multirow{3}{*}{$\begin{array}{c}\text { Factor time of storage } \\
\text { (days) }\end{array}$} & \multicolumn{2}{|c|}{ Factor type of storage } \\
\hline & Outdoor storage & Indoor storage \\
\hline & \multicolumn{2}{|c|}{ Ash content (\%) } \\
\hline 30 & $0.9 \mathrm{aD}$ & $1.8 \mathrm{aA}$ \\
\hline 60 & $4.8 \mathrm{aBC}$ & $1.5 \mathrm{bA}$ \\
\hline 90 & $3.2 \mathrm{aCD}$ & $2.9 \mathrm{aA}$ \\
\hline 120 & $6.4 \mathrm{aB}$ & $2.3 \mathrm{bA}$ \\
\hline 150 & $10.6 \mathrm{aA}$ & $1.5 \mathrm{bA}$ \\
\hline 180 & $12.1 \mathrm{aA}$ & $1.9 \mathrm{bA}$ \\
\hline
\end{tabular}

Averages followed by the same letter are not significantly different ; lower case letters indicate comparison in the rows (type of storage); upper case letters indicate comparison in columns (time of storage).

However, according to Figure 4, there was an increase in the ash content of wood chips in the outdoor storage, which could be an indicative of contamination by other particles, such as soil attached to the chips or dust from the processes of timber harvesting and transportation. Such results were also observed by Furtado et al. (2012). Furthermore, biomass residues stored outdoors kept low ash content between 30 and 90 days, increasing significantly after 120 days.

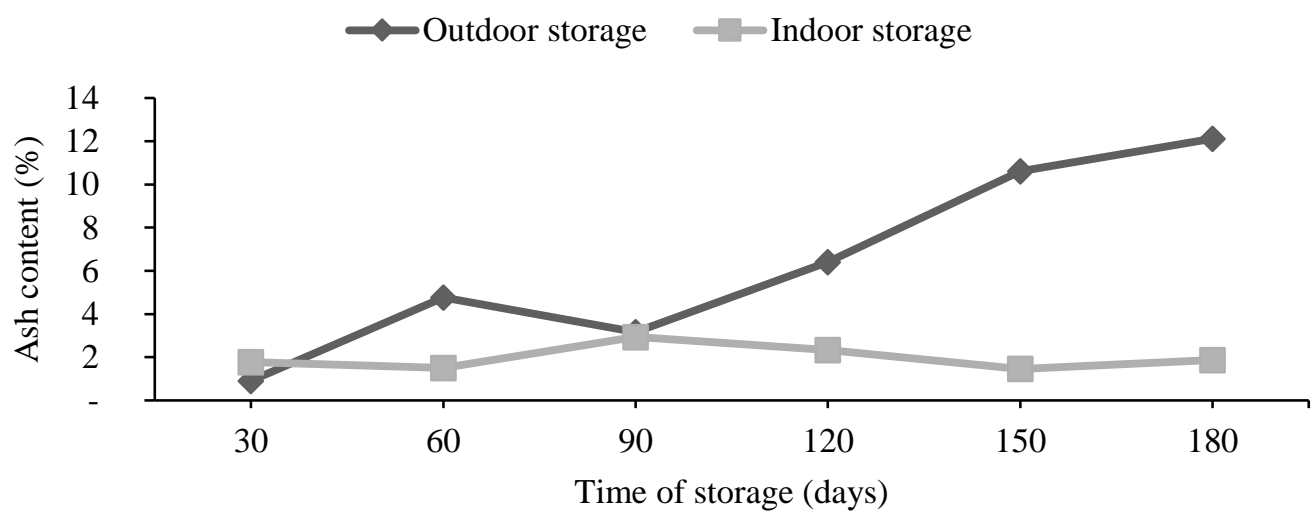

Figure 4. Variation of ash content of chips from forest biomass residues stored outdoors and indoors.

Figura 4. Comportamento do teor de cinzas de cavacos de biomassa residual estocada em campo e dos cavacos estocados na indústria.

Comparing the types of storage, it is evident the superiority of the indoor storage on the material stability, thus allowing the achievement of higher calorific values. In addition, the indoor storage was responsible for low levels of ash content throughout the evaluated time, whereas outdoor storage resulted in increased levels of ash content, e.g., at 180 days. Indoor storage resulted in $1.9 \%$ of ash, whereas outdoor storage resulted in $12.1 \%$ (eightfold more ash). Finally, the increase in ash content explains the reduction in gross calorific value of biomass stored outdoors, which was also found by Furtado et al. (2012).

\section{CONCLUSIONS}

- The moisture content, gross calorific value, net calorific value and ash content were influenced by the type and time of storage of biomass residues from timber harvesting.

- There was reduction in the gross calorific value and net calorific value and increase in moisture and ash content by increasing the time of outdoor storage of biomass residues.

- There was stability in gross calorific value and ash content, reduction in moisture content, and increase in net calorific value of chips processed and stored indoors, as the time of storage increased. 
- The storage time of residues from wood harvesting for energy production is around 30 days, whereas the time for chips processed and storage at industry is 60 days. After this time, there is no decrease of moisture content of the materials.

- Processing biomass residues from timber harvesting and subsequently storing the chips indoors proved to be the best procedure for optimization of the energy potential of the material.

\section{REFERENCES}

AKPINAR, A.; KÖMÜRCÜ, M. I.; KANKAL M.; ÖZÖLÇER, I. H.; KAYGUSUZ, K. Energy situation and renewables in Turkey and environmental effects of energy use. Renewable and Sustainable Energy Reviews. v. 12, n. 8, p. 2013-2039, 2008.

ALMEIDA, N. F.; CAMARGO, D. T.; ARRIEL, D. A. A.; MORI, F. A. Avaliação das propriedades dos resíduos de Pinus patula em diferentes períodos de armazenamento visando a cogeração de energia. Floresta, Curitiba, v. 40, n. 2, p. 269-274, 2010.

AMERICAN SOCIETY FOR TESTING AND MATERIALS. ASTM E711-87: Standard Test Method for Gross Calorific Value of Refuse-Derived Fuel by the Bomb Calorimeter, 2004.

AMERICAN SOCIETY FOR TESTING AND MATERIALS. ASTM E871-82: Standard Test Method for Moisture Analysis of Particulate Wood Fuels, 2013.

ASSOCIAÇÃO BRASILEIRA DE NORMAS TÉCNICAS (ABNT). NBR 14929. Madeira - Determinação do teor de umidade de cavacos - Método por secagem em estufa, Rio de Janeiro, 2003.

BRAND, M. A. Energia de biomassa florestal. Rio de Janeiro: Interciência, 1 ed. 2010, 131p.

BRAND, M. A.; MUÑIZ, G. I. B.; BRITO, J. O.; QUIRINO, W. F. Influência das dimensões da biomassa estocada de Pinus taeda L. e Eucalyptus dunnii Maiden na qualidade do combustível para geração de energia, Revista Árvore, Viçosa, v. 38, n. 1, p. 175-183, 2014.

BRAND, M. A.; BRITO, J. O.; QUIRINO, W. F.; MUÑIZ, G. I. B. Influência da época de estocagem na qualidade da biomassa florestal para a geração de energia. Floresta, Curitiba, v. 42, n. 2, p. 369- 80, 2012.

BRAND, M. A.; MUÑIZ, G. I. B.; QUIRINO, W. F.; BRITO, J. O. Storage as a tool to improve wood full quality,Biomass and Bioenergy, Cambridge, v. 35, n. 7, p. 2581-2588, 2011.

BRAND, M. A.; MUÑIZ, G. I. B. Influência da época de colheita da biomassa florestal sobre sua qualidade para a geração de energia. Scientia Florestalis, Piracicaba, v. 38, n. 88, p. 619-628, 2010.

FURTADO, T. S.; FERREIRA, J. C.; BRAND, M. A.; MUÑIZ, G. I. B.; QUIRINO, W. F. Mapeamento da frequência de uso e características da biomassa florestal utilizada para a geração de energia em Lages, SC. Ciência Florestal, Santa Maria v. 29, n. 4, p. 795-802, 2012.

LEITE, E. R. S.; PROTÁSIO, T. P.; ROSADO, S. C. S.; TRUGILHO, P. F.; TONOLI, G. H. D.; BUFALINO, L. Avaliação da qualidade da madeira de Coffea arábica L. como fonte de bioenergia. Cerne, Lavras, v. 20, n. 4, p. 541-549, 2014.

NEUHOF, I.; MERGLER, F.; ZORMAIER, F.; WEINERT, B.; HÜTTL, K. Hackschnitzelrichtiglagern. In: LWF MERKBLATT, 11, Bayerische Landesanstaltfür Wald und Forstwirtschaft. 4 p. 2014.

SCHOLZ. V.; IDLER, C.; GOTTSCHALK, K.; EGERT, V.; PFISTER, W. Energieverlust und Schimmelpilzentwicklungbei der Lagerung von Feldholz-Hackgut, 39 ed., Institutfür Agrartechnik Bornim e. V. (ATB): Potsdam-Bornim, Alemanha, 2005. 155 p.

SOUZA, M. M.; SILVA, D. A.; ROCHADELLI, R.; SANTOS, R. C. Estimativa de poder calorífico e caracterização para uso energético de resíduos da colheita e do processamento de Pinus taeda. Floresta, Curitiba, v. 42, n. 2, p. 325-334, 2012.

VALE, A. T.; MENDES, R. M.; AMORIM, M. R. S.; DANTAS, V. F. S. Potencial energético da biomassa e carvão vegetal do epicarpo e da torta de pinhão manso (Jatrophacurcas). Cerne, Lavras, v. 17, n. 2, p. 267-273, 2011.

VIEIRA, A. C. Caracterização da biomassa proveniente de resíduos agrícolas. 56 p. Dissertation (MSc in Energy in Agriculture) - State University of Western Paraná, Cascavel, 2012.

FLORESTA, Curitiba, PR, v. 48, n. 1, p. 09-18, jan./mar. 2018

Oro. D. et.al.

ISSN eletrônico 1982-4688

DOI: $10.5380 /$ rf.v48 i1.46628 
FLORESTA, Curitiba, PR, v. 48, n. 1, p. 09 - 18, jan./mar.2108

Oro. D. et.al. 